\title{
동해 부유식 해상풍력발전단지 내 참다랑어 양식장 조성에 관한 연구 A Study on the Building of Tuna Farming in Floating Offshore Wind Power Generation Field at East Sea
}

\author{
최군환* · 김미정** · 장기호*** · 김효선**** \\ Gun Hwan Choi*, Mi Jeong Kim**, Ki Ho Jang*** and Hyo Seon Kim****
}

\begin{abstract}
요 지 : 재생에너지 3020 이행계획, 한국판 뉴딜 계획 등에 따라 신재생에너지 생산 비중 증가 대응과 해상풍력발 전 $12 \mathrm{GW}$ 건설을 위해 어업생활권 점유 대안 마련과 주민 수용성 제고를 위한 방안이 요구된다. 본 연구는 동해에 적합한 해상풍력발전단지와 연계한 수산자원 공존모델의 차별방안을 제시하였다. 동해는 부유식 해상풍력 발전단지 조성의 최적지로 단지 내 공유수면을 활용하여 외해양식에 적합한 고부가가치 어종인 참다랑어를 양식함으로써 에 너지 생산, 수산자원 개발, 관광산업화를 통한 이익 창출로 경제적 효과 발생을 예측하였다. 또한, 운영관리 기술 공 유 등으로 예산 감축, 스마트 관리 추진과 어민소득 증대 가능성을 확인하였다.
\end{abstract}

핵심용어 : 부유식 해상풍력발전, 공존모델, 외해양식, 참다랑어, 경제적 효과

\begin{abstract}
We need measures that can come up with alternative about fishery living zone and enhance local acceptance for responding to the increase in the proportion of renewable energy production and construction of 12GW Offshore wind power according to Korea's Renewable Energy 3020 initiative and Korean-version New Deal. In this study, We suggest that differentiation plans of co-location model in connection with offshore wind power generation suitable for the East Sea. The East Sea is an optimal site for building of a floating offshore wind power generation(FOWPG) field. It is expected that economic effects like energy production, aquatic resource development and tourism industrialization by farming bluefin tuna which is high valued fish and suitable for offshore aquaculture on public waters in FOWPG field. And we can confirm that budget reduction, smart management by sharing operation management technology and increase in fishermen income.
\end{abstract}

Keywords : floating offshore wind power generation(FOWPG), co-location model, offshore aquaculture, bluefin tuna, economic effect

\section{1. 서 론}

국내는 2017년 재생에너지 3020 이행계획 발표로 재생에너 지 보급을 태양광, 풍력 중심으로 확대하고 해상풍력 약 $12 \mathrm{GW}$ 를 포함한 총 $16 \mathrm{GW}$ 의 육·해상풍력발전단지 추가건설을 계획 하고 2025년 이후 부유식 해상풍력 실증단지 조성을 위한 사 업을 추진하고 있다. 또한, 최근 한국판 뉴딜 종합계획은 대규 모 고정식 및 부유식 해상풍력단지 입지발굴을 위해 최대 13 개 권역의 풍황 계측.타당성 조사 지원 및 배후·실증 단지 단 계적 구축 등 지속 가능한 신재생에너지 확산기반 구축을 제 시하였다. 하지만, 해상풍력발전에 대한 지역 수용성 확보 등
의 문제로 실증사업의 확산사업은 지연되고 있으며, 어민의 생 활어업권 침해에 따른 소득원 보상이 주요 쟁점이 되고 있다. 동해는 부유식 해상풍력 발전단지 입지조건으로 포항에서 제주도까지 해안선으로부터 $20 \mathrm{~km}$ 내외 지역 수심은 130 $150 \mathrm{~m}$, 연평균 풍속 $7.5 \sim 8.5 \mathrm{~m} / \mathrm{s}$ 로 경제성은 충분한 것으로 파악되었다(Choi et a1., 2018). 하지만, 고정식 해상풍력에 비해 깊은 수심으로 먼바다에 설치되기 때문에 육상 풍력발 전 및 고정식 해상풍력발전단지 조성 시 발생하는 민원과 차 이가 있으나 국내는 관련 자료 및 정보가 부족하여 주민의 인 지도가 낮은 편이다.

해상풍력단지 사회적 수용성 제고는 필연적 사항으로 유럽

*한동대학교 부유식해상풍력발전연구소 연구소장(Director of Institute, Research Institute of Floating Offshore Wind-power Generation Farm Field, Handong Global University)

**한동대학교 부유식해상풍력발전연구소 수석연구원(Corresponding author: Mi Jeong Kim, Principal Research Engineer of Institute, Research Institute of Floating Offshore Wind-power Generation Farm Field, Handong Global University, 558 Handong-Ro, Heunghae-eup, Bukgu, Pohang, Gyung-buk 37554, Korea, Tel: +82-545-260-3132, Fax: +82-54-260-1429, kim386@handong.edu)

***한동대학교 부유식해상풍력발전연구소 책임연구원(Senior Research Engineer of Institute, Research Institute of Floating Offshore Windpower Generation Farm Field)

****한동대학교 부유식해상풍력발전연구소 주임연구원(Associate Research Engineer of Institute, Research Institute of Floating Offshore Wind-power Generation Farm Field) 
일부 국가에서는 양식, 관광, 낚시 및 레저 등 사업모델 개 발을 시도하고 있으며, 미국은 해상유전에 상업적 양식 가능 성 파악을 위해 외해양식을 처음으로 시도하여 해상 가두리 양식까지 확대하였다(Kang et al., 2016). 해상풍력 공존형 (Co-location) 프로젝트는 2012년 영국 연안 해상풍력발전시 설에서 어패류 양식을 장려하기 위해 시작된 프로젝트이며, 국내는 서남해 해상풍력 산업융합설비사업으로 바다목장 사 업의 경제적 효과분석에서 어획효과 증대, 어가의 소득증대 등 긍정적 효과가 있는 것으로 산출되었다(Choi et al., 2015). 풍력 터빈 자켓을 활용한 재킷형 가두리(Jacket-Cage) 양식개념은 자켓 지지구조물을 공유하여 사용할 경우 어망으 로 인한 추가하중, 부식, 해양생물 성장, 조류 포식자의 터빈 또는 지지구조물과의 충돌 등 보완이 요구된다(Wei, 2015).

국내 수산물 소비량은 2018년 기준 $68.1 \mathrm{~kg} /$ 인으로 세계 주 요국 중 1 위이며, 동해 대표 수산물 브랜드인 영덕 대게는 2020 년 기준 15,548 톤으로 2015 년 대비 $63 \%$ 급감하여 수산 자원은 식량안보 차원으로 접근해야 하며 대체 어종 개발을 통한 소득증대가 시급한 실정이다.

외해양식 시설물은 2005년 제주도 외해양식영어조합법인 에서 미국 외해양식설비를 도입하여 최초로 외해 가두리 양 식을 시작하였으며, 2010년 제주도와 전라남도에서 국내 최 초 외해양식 정식 면허를 취득하였다(NIFS, 2012). 2019년 기준 외해 양식장은 총 10 개소 $(198 \mathrm{ha})$ 로 국내 외해양식 어 종은 연어, 고등어, 참돔, 돌돔, 방어, 참다랑어가 있으며, 이
중 동해는 연어, 방어 등을 양식하고 있다. 참다랑어는 2006 년 국립수산과학원의 참다랑어 양식기술개발 로드맵 연구를 시작으로 경남 욕지도 2 개소와 제주 서귀포 1 개소에서 면적 15 20 ha로 내파성 가두리, 수중가두리, 부침식 가두리 형태 로 운영되고 있으나 안정적 종자확보, 태풍, 적조 등의 해양 환경 변화 대응은 필수적 요구사항이다.

본 연구는 기후변화에 따른 국내·외적 에너지 기술 전망, 수산자원 변화에 대응하고 동해 부유식 해상풍력 발전단지 조 성과 수산업공존을 위한 방안으로 수심 $35 \mathrm{~m}$ 이상의 외해역 에 참다랑어 양식 가능성과 지속 가능한 경제적 가치 등을 제 시하였다. 기존의 해상풍력과 수산업 공존모델형인 하부구조 물 및 공간 또는 내수면이 아니라 부유식 해상풍력발전단지 내 가두리를 설치하여 해상풍력발전단지 모니터링 시스템을 공유하고 통합·운영하는 방안, 연계 기술, 지역 주민의 수익 창출 결과 등을 검증함으로써 글로벌 에너지 패러다임에 대 응하고 부유식 해상풍력발전단지 조성의 긍정적 인식변화를 추구하고 재생에너지와 수산자원 연계를 통한 어민 소득 증 대 및 지역 경제 활성화의 가능성을 확인하였다.

\section{2. 해상풍력발전단지 조성 공학적 이론 및 단지 내 가두리 양식 산업 공존모델 방안}

\section{1 해상풍력발전단지 공학적 이론 및 관련 기술}

부유식 해상풍력발전단지 조성에 필요한 공학적 이론은 설

Table 1. Theory for FOWPG (Floating Offshore Wind Power Generation) field building

\begin{tabular}{|c|c|c|c|}
\hline Classification & Main formula & & \\
\hline $\begin{array}{l}\text { Floating } \\
\text { body } \\
\text { theory }\end{array}$ & $B=\rho \vec{\nabla}^{3}$ & $\begin{array}{l}B: \text { Buoyancy } \\
\rho \text { : Density } \\
\vec{\nabla}^{3}: \text { Cubic metrics vect }\end{array}$ & \\
\hline $\begin{array}{l}\text { FOWPG } \\
\text { array } \\
\text { interference }\end{array}$ & $\begin{aligned} W_{e T} & =B^{(3 \sim 5)} \\
& =B^{(3 \sim 5)+\alpha} \\
W_{e L} & =B^{(5 \sim 9)} \\
& =B^{(5 \sim 9)+\beta}\end{aligned}$ & $\begin{array}{l}W_{e T}: \text { Transverse length } \mathrm{f} \\
W_{e L}: \text { Longitudinal length } \\
\alpha \text { : Horizonal mooring ra } \\
\text { of X axis direction } \\
\beta \text { : Vertical mooring rais } \\
\mathrm{Y} \text { axis direction } \\
\text { (1): Fixed type WTG ar } \\
\text { (2): Floating type WTG }\end{array}$ & $\begin{array}{l}\text { ct } \\
\text { speed, moving length } \\
\text { eed, moving length of }\end{array}$ \\
\hline $\begin{array}{l}\text { Anchor } \\
\text { formulation }\end{array}$ & $H=\lambda W$ & $\begin{array}{l}H \text { : Holding force of anc } \\
\lambda \text { : Coefficient of holding } \\
W: \text { Weight }\end{array}$ & \\
\hline \multirow{6}{*}{$\begin{array}{l}\text { Floating } \\
\text { breakwater }\end{array}$} & $A=\frac{8 h}{3}\left(y_{1}+3 y_{2}+3 y_{3}+2 y_{4} \ldots 3 y_{n-1}+y_{n}\right)$ & $\begin{array}{l}A: \text { Waterplane area } \\
h=x_{n}-x_{n-1}\end{array}$ & Simpson's rule \\
\hline & $\eta(x, t)=A \cos (k x-\omega t)=A \cos \Theta$ & $\eta$ : Surface wave shape & \multirow{3}{*}{$\begin{array}{l}\text { Airy wave theory } \\
\text { (Linear water surface } \\
\text { waves) }\end{array}$} \\
\hline & $\phi(x, y, t)=\frac{g A}{\omega} e^{k u} \sin (k x-\omega t)$ & $\phi$ : Velocity potential & \\
\hline & $\omega^{2}=g k$ & $\omega$ : Circular frequency & \\
\hline & $I \frac{d^{2} \phi}{d t^{2}}+M=0$ & Equation of motion & \multirow{2}{*}{ Ship motion } \\
\hline & $T_{\phi}=\frac{1.108 k}{\sqrt{G M}}$ & Rolling period & \\
\hline
\end{tabular}




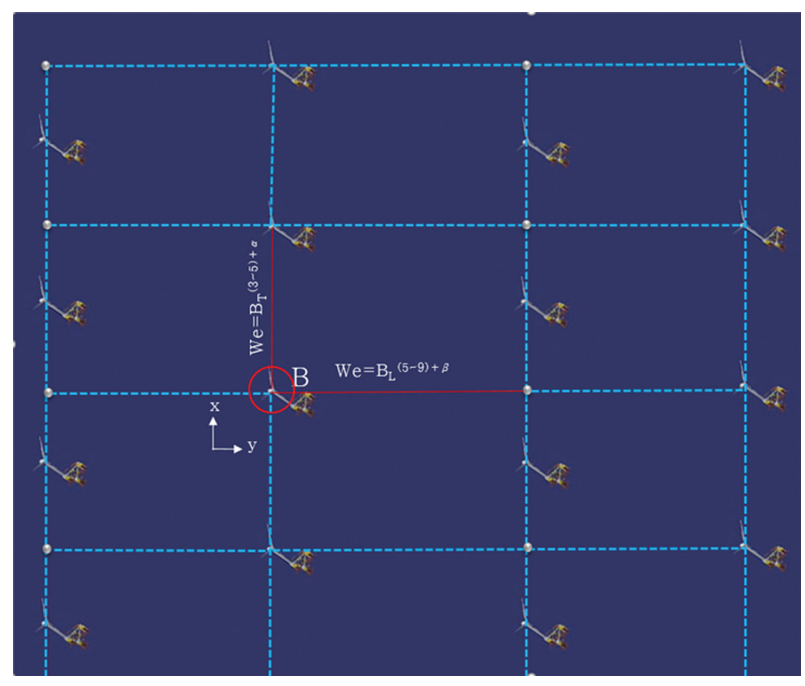

Fig. 1. Layout plot of FOWPG field by wake effect.

비 구조 및 해양의 특성을 다각적 측면에서 접목·융합시켜야 하지만 Table 1은 해상의 풍력발전기 부유체, 해저 고정을 위 한 앵커, 해상구조물을 파랑으로부터 보호하기 위한 부유식 방파제 설계(Choi et al., 2019)를 위해 사용한 이론 중심으 로 정리하였다. 특히, 부유식 해상풍력발전단지의 발전기 배 치는 매우 중요한 설계 인자로 부유식의 경우 후류효과(Wake effect)에 의해 로터 블레이드(Rotor blade)의 5 9배를 유지해 야 하며 계류에 의한 이동성을 고려하여 배치해야 한다(Choi, 2019). Fig. 1은 부유식 해상풍력발전기 배치 효과를 적용하 여 나타낸 조성도이다.

Table 2는 부유식 해상풍력발전단지를 조성, 운영관리를 위 해 필요한 기술 등을 나타낸 것으로 모니터링 기술, 시설물 보호 기술, 단지 조성을 위한 주민 수용성 제고를 위한 방안 들을 포함하고 있다.

\section{2 동해 참다랑어 종자 확보}

동해 해역 수온은 쿠로시오 해류 및 기후 온난화 등의 영 향으로 참다랑어 치어가 겨울나기 위한 최저온도 $12^{\circ} \mathrm{C}$ 를 유 지하며, 수백 $\mathrm{m}$ 만 나가도 외향 영향을 받고 수심이 깊어지는 조건을 갖추고 있다.

종자 및 치어 확보는 동해 해상에서 포획된 참다랑어를 해 상풍력발전단지 내 외해 가두리로 이송하여 양식하는 방안,

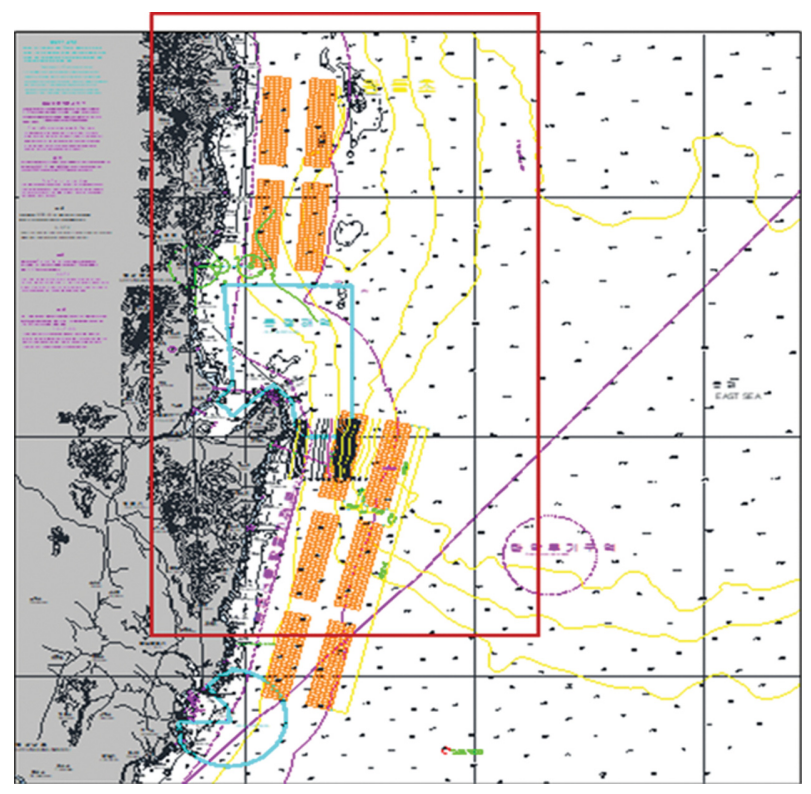

Fig. 2. Floating offshore wind power generation field potential generation capacity and estimated layout at East Sea.

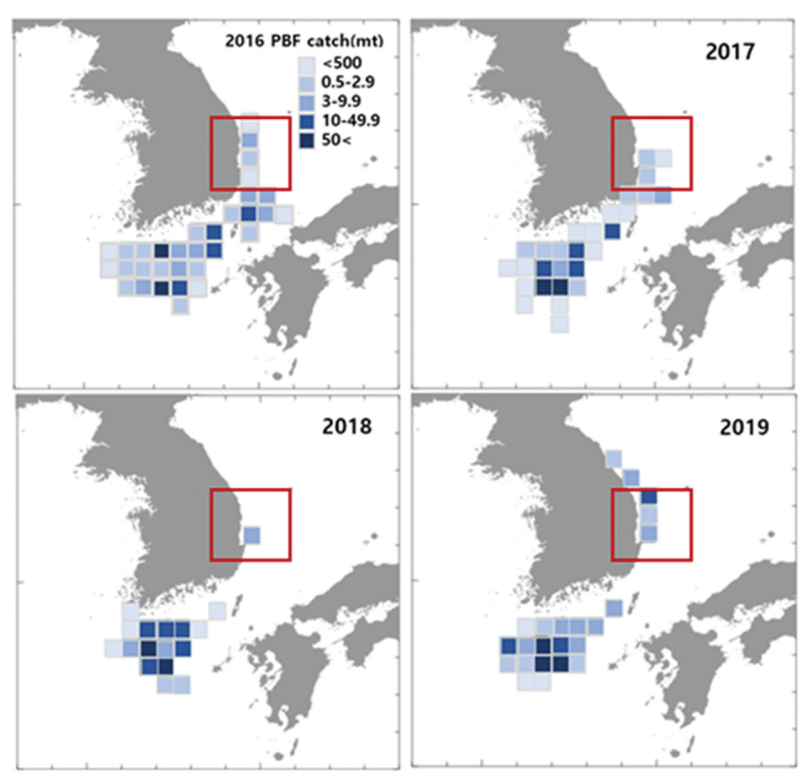

Fig. 3. Catch distribution of Pacific bluefin tuna caught in the Korean water, 2016 2019.

육상의 종자 생산사업을 통해 육상수조에서 생산된 수정란 및 치어를 사육하여 외해 가두리에서 양식하는 방안과 일본 등

Table 2. Related technologies with FOWPG

\begin{tabular}{ll}
\hline \hline \multicolumn{1}{c}{ Item } & \multicolumn{1}{c}{ Summary } \\
\hline Floating breakwater & Protection of offshore wind farms and offshore aquaculture by blocking wave energy \\
\hline O-STAR Radar & $\begin{array}{l}\text { Real-time remote monitoring of offshore facilities using X, Ka band radar in the } \\
\text { target sea area and AI correction }\end{array}$ \\
\hline Offshore Defence Detector & Predicting and responding to disasters through marine environment monitoring \\
\hline Lighting protection S/S & Lightning protection device and system for offshore wind power facility protection \\
\hline Bluefin tuna fish farming & Co-location model project to increase profit of local fishermen \\
\hline
\end{tabular}


Table 3. Costs incurred in transporting juvenile bluefin tuna

\begin{tabular}{|c|c|c|c|}
\hline & Item & "Cost(unit: $\left.10^{6} \times \mathrm{KRW}\right)$ & Remark \\
\hline Case 1 & $\begin{array}{l}\text { Import of Japanese } \\
\text { juvenile, transport } \\
\text { to the South Sea }\end{array}$ & $\begin{array}{l}0.25 \mathrm{KRW} / \text { fish } \times 1,000 \text { fish } \\
=250 \mathrm{KRW}\end{array}$ & $\begin{array}{l}\text { - Standard on fishery resources transport } \\
\text { approval: } 1 \mathrm{fish} / \mathrm{m}^{2}, 7 \mathrm{~kg} \text { or less } \\
\text { - Transportation cost included }\end{array}$ \\
\hline Case 2 & $\begin{array}{l}\text { Capture in the } \\
\text { East Sea, transport } \\
\text { to the South Sea }\end{array}$ & $\begin{array}{l}45 \mathrm{KRW} / 1 \text { Time (Charter) } \\
+30 \mathrm{KRW} \text { (Transport cage manufacture) } \\
=75 \mathrm{KRW}\end{array}$ & $\begin{array}{l}\text { - Management cost Excluded } \\
\text { - Transport cage: inner dia. } 20 \mathrm{~m}\end{array}$ \\
\hline
\end{tabular}

에서 치어를 수입하는 것이다. 일본의 참다랑어 양식도 안정 된 사육을 위해 최저 수온 $13^{\circ} \mathrm{C}$ 이상, 수심 $30 ~ 50 \mathrm{~m}$ 주변 해역에서 종묘를 확보한 후 외해로 진출하고 있다.

Fig. 2는 동해안의 영해한계선까지 부유식 해상풍력단지 잠 재발전용량 및 예상 배치도를 나타낸 것으로 잠재발전 가능 면적은 부유식 해상풍력은 해안선에서 $5 \mathrm{~km}$ ( 영해한계선)까 지 $6 \mathrm{MW}$ 급 기준 $6,386 \mathrm{~km}^{2}$, 고정식 해상풍력은 해안선에서 $5 \mathrm{~km}$ 까지 $3 \mathrm{MW}$ 급으로 $1,548 \mathrm{~km}^{2}$ 로 추정되었다.

Fig. 3은 2016년 이후 우리나라 연근해에서 참다랑어(Pacific bluefin tuna)가 어획된 해역으로, 주로 제주도에서는 1 월부터 3월 선망(Purse seine fleets)으로, 일부는 일 년 내내 동해안 의 정치망(Set net)을 통해 2018년 535톤, 2019년 9월 기준 567톤이 어획된 것으로 조사되었다(Kim et al., 2019) 동해에 서 포획된 참다랑어를 해상풍력발전단지 내 가두리로 이송하 여 외해양식으로 연계할 수 있음을 알 수 있다.

Table 3은 치어를 확보하는 과정에서 발생하는 비용을 조 사한 것으로 국내 참다랑어 양식은 대량 수정란 확보기술의 한계로 일본 치어 수입에 의존하고 있으나 이송시 발생 폐사 책임은 국내 경영체가 부담해야 한다. 현재 운영 중인 남해 안 양식장으로 수입.이송할 경우 1,000 마리 기준 2 억 5 천만 원 이 소요되며, 동해에서 포획된 치어를 이송할 때는 7천 5백 만 원 이상의 이송 비용이 필요한 것으로 조사되었다. 또한, 동해에서 정치망으로 포획된 참다랑어는 평균 $10 \mathrm{~kg}$ 급으로 전 문적인 이송 기술이 요구된다. 본 연구에서 제시한 동해 가 두리 양식장에서 사육할 경우, 장거리 이송 등에 따른 추가 적 비용 및 폐사 등의 위험부담을 감소시킬 수 있다.

\section{3 부유식 해상풍력발전단지 조성 연계 양식장 설치}

정부는 2024년까지 부유식 해상풍력 시스템 개발 완료예 정으로 주민 수용성 연관 대체어장확보, 해양환경변화에 따 른 어족자원 감소 극복을 통한 소득원 창출과 외해양식 스마 트플랜트 구축을 추진하고 있으며, 서남해 고정식 해상풍력 발전단지는 해상풍력 하부구조물을 활용하여 2022년까지 단 지 외각부 테두리를 따라 양식장 조성, 인공어초 설치 등을 통해 수산업 공존모델 실증사업을 하고 있다.

Fig. 4는 $5 \mathrm{MW}$ 급 부유식 해상풍력발전단지와 직경 $30 \mathrm{~m}$ 가두리 양식시설 공존모델의 개념도로 기존의 해상풍력발전 단지 수산 공존형인 하부구조물 및 외부 공간을 활용하는 방 식과 달리 발전단지 내 후류효과에 따른 배치 간격인 이격거 리 750 1,000 m 공유수면을 활용하여 참다랑어 가두리를 설 치하는 모델을 제시한 것이다. 부유식 계류 시스템 설계기준 으로 수심 $100 \mathrm{~m}$ 내외에서 9 개의 가두리 설치가 가능한 것 으로 추정되었다. 참다랑어 양식 가두리는 동해의 파랑, 조류 등의 유체력에 대한 강도 분석, 소재에 따른 응력 분석 등이 필요하며, 태풍, 적조 등의 피해 대응을 위해 남해의 내파성 가두리와 제주의 수중가두리의 장.단점을 보완한 부침성 기 능이 추가될 필요가 있다.

Table 4는 해상풍력발전단지 내 참다랑어 양식장을 운영할 경우 예측되는 수익을 산출한 것으로 직경 $30 \mathrm{~m}$ 기준 총 체 적은 $14,000 \mathrm{~m}^{3}$, 참다랑어 사육밀도 $2 \sim 3 \mathrm{~kg} / \mathrm{m}^{3}$ 로 약 $30 \mathrm{~kg}$ 까 지 사육할 경우 1,000 여 마리를 수용할 수 있으며 가두리 1 개당 4.7 억 원/년으로 $500 \mathrm{MW}$ 해상풍력발전단지 조성 후 3,400 억 원/년 수익 창출을 기대할 수 있다.
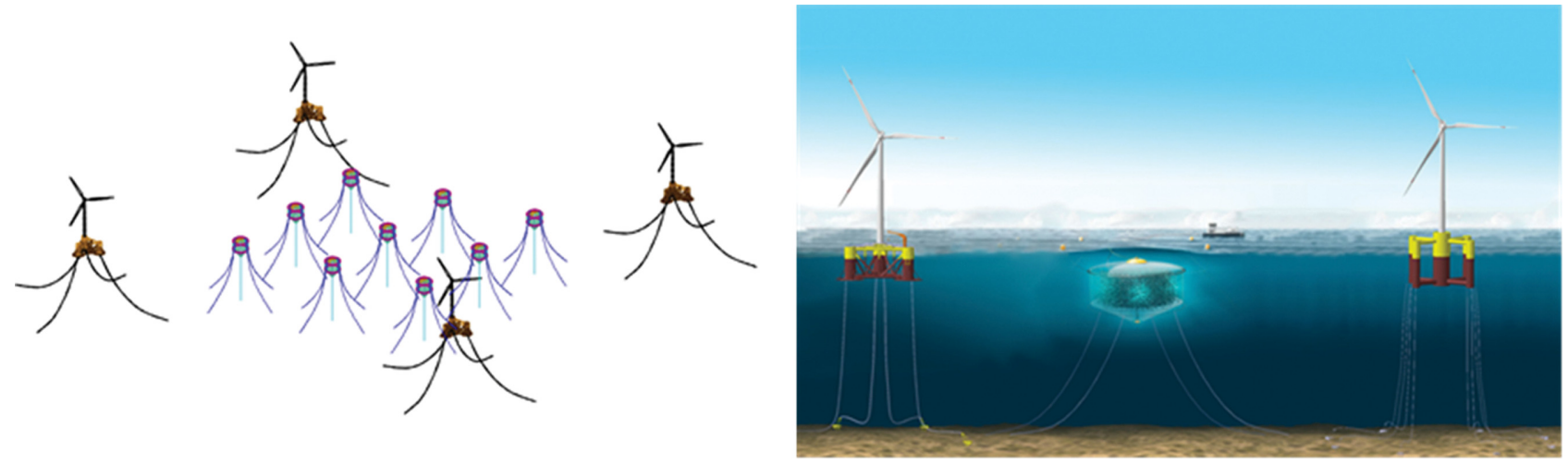

Fig. 4. Key map of aquaculture co-location model in floating offshore wind power field at East Sea. 
Table 4. Predicting profit by farm operation in $0.5 \mathrm{GW}$ FOWPG field

\begin{tabular}{|c|c|c|c|}
\hline Item & \multicolumn{2}{|c|}{ Profit (unit: $10^{6} \times \mathrm{KRW}$ ) } & Remark \\
\hline \multirow[t]{2}{*}{$\begin{array}{c}\text { Profit/cage } \\
(\text { Cage dia.: } 30 \mathrm{~m})\end{array}$} & \multicolumn{2}{|c|}{$\begin{array}{l}0.7 \mathrm{KRW} / \text { fish } \times 1,000 \mathrm{fish} / \text { cage } \\
=700 \mathrm{KRW} / \text { cage }\end{array}$} & $\begin{array}{l}\text { - Rearing period: } 18 \text { months } \\
\text { - Production cost: } 0.8 \mathrm{KRW} \\
\text { - Sale price: } 1.5 \mathrm{KRW} / 30 \mathrm{~kg}\end{array}$ \\
\hline & $467 \mathrm{KRW} /$ cage & & Per 12 months \\
\hline \multirow{4}{*}{$\begin{array}{l}\text { Profit } / 500 \mathrm{MW} \\
(0.5 \mathrm{GW}) \text { filed } \\
(5 \mathrm{MW} \text { grade, } \\
100 \text { Units })\end{array}$} & \multirow{2}{*}{$\begin{array}{l}\text { Installing } 1 \text { cage each } \\
\text { in FOWPG field }\end{array}$} & $\begin{array}{l}700 \mathrm{KRW} / \text { cage } \times 81 \text { cage } \\
=56,700 \mathrm{KRW}\end{array}$ & 81 cages in FOWPG field \\
\hline & & $37,800 \mathrm{KRW}$ & Per 12 months \\
\hline & \multirow{2}{*}{$\begin{array}{l}\text { Installing } 9 \text { cage each } \\
\text { in FOWPG field }\end{array}$} & $\begin{array}{l}700 \mathrm{KRW} / \text { cage } \times 729 \text { cage } \\
=510,300 \mathrm{KRW}\end{array}$ & 729 cages in FOWPG field \\
\hline & & 340,200 KRW & Per 12 months \\
\hline
\end{tabular}

Table 5. Scope of farm management in connecting with FOWPG operating monitoring technology

\begin{tabular}{|c|c|c|c|}
\hline \multicolumn{3}{|c|}{ "FOWPG field technology } & \multirow[b]{2}{*}{$\begin{array}{l}\text { Utilization tech. with tuna } \\
\text { farming management }\end{array}$} \\
\hline & & $\begin{array}{l}\text { Estimated } \\
\text { budget ( } 100 \\
\text { million won) }\end{array}$ & \\
\hline \multirow{4}{*}{$\begin{array}{l}\text { Integrated } \\
\text { operation and } \\
\text { maintenance tech. }\end{array}$} & $\begin{array}{c}\text { CMS (Condition } \\
\text { Monitoring System) \& } \\
\text { SCADA (Supervisory } \\
\text { Control And Data } \\
\text { Acquisition) }\end{array}$ & 22 & $\begin{array}{l}\text { Farm and mooring system monitoring, farm auto- } \\
\text { matic control system, cage sinking \& floating remote } \\
\text { control }\end{array}$ \\
\hline & $\begin{array}{l}\text { Predictive } \\
\text { maintenance tech. }\end{array}$ & 42 & $\begin{array}{l}\text { Farm data collection, data integrated operation, remote } \\
\text { control, environment of fishing ground monitoring } \\
\text { (underwater camera, censor etc.): un-manned auto- } \\
\text { mate feeding, residual feed amount prediction, tuna } \\
\text { activity, growth pattern etc. }\end{array}$ \\
\hline & $\begin{array}{l}\text { Integrated control } \\
\text { center }\end{array}$ & 115 & $\begin{array}{l}\text { Control center infrastructure utilization Integrated } \\
\text { operation, action: weather, cold pool, water quality, } \\
\text { physical ocean conditions }\end{array}$ \\
\hline & Sub total & 179 & - \\
\hline \multirow{4}{*}{$\begin{array}{l}\text { Disaster risk } \\
\text { situation monitoring } \\
\text { and disaster safety } \\
\text { response system tech. }\end{array}$} & $\begin{array}{c}\text { Physical security } \\
\text { monitoring system tech. }\end{array}$ & 25 & $\begin{array}{l}\text { Integrated management of marine environment mon- } \\
\text { itoring area: red tide, oil spill }\end{array}$ \\
\hline & $\begin{array}{l}\text { Risk prediction, early } \\
\text { detection, situation } \\
\text { propagation tech. }\end{array}$ & 25 & $\begin{array}{l}\text { Accident situation awareness, remote action, joint } \\
\text { response }\end{array}$ \\
\hline & $\begin{array}{l}\text { Disaster safety } \\
\text { response scenario } \\
\text { development }\end{array}$ & 25 & $\begin{array}{l}\text { Manual for systematic joint response in marine disas- } \\
\text { ter, risk }\end{array}$ \\
\hline & Sub total & 75 & - \\
\hline \multicolumn{2}{|c|}{ Total } & 254 & - \\
\hline
\end{tabular}

\section{4 해상풍력발전단지 운영·관리 통합한 양식장 스마트화}

세계적 양식기업은 첨단기술 및 시스템을 통해 양식어업을 관리하고 있으며, 국내는 기업화, 스마트화를 통하여 고부가 가치 양식어업 등을 통해 2030년까지 스마트 양식장 보급률 을 $12.5 \%$ 까지 확대 계획하고 혁신적 비전을 제시하고 있다. 해상의 풍력발전단지를 최적 운영·관리, 재난안전사고 예방 및 대응체계를 구축하기 위해 요구되는 기술 및 시스템을 양식 장 운영에 활용하고 스마트화를 도입한다면 예산의 중복적 투 자를 축소할 수 있으며, 수산업 기술의 자동화 및 지능화를
추구할 수 있다. 스마트 양식 기술 중 사육환경 측정과 자동 제어 기술은 가장 큰 부가가치를 창출할 수 있는 분야로(Lee et al., 2021) 관련 운영기술을 연계할 수 있다.

Table 5는 재생에너지 3020 정책목표 달성을 위해 부유식 해상풍력 $2 \mathrm{GW}$ 개발 기준 시 풍력단지 운영관리기술 개발을 위한 소요 예산 254억 원 및 양식장에 활용할 수 있는 기술 을 나타낸 것이다. 운영을 위한 기술뿐만 아니라 육·해상관 리 인프라도 공동 이용함으로써 관리비용 감소도 가능할 것 이다. 


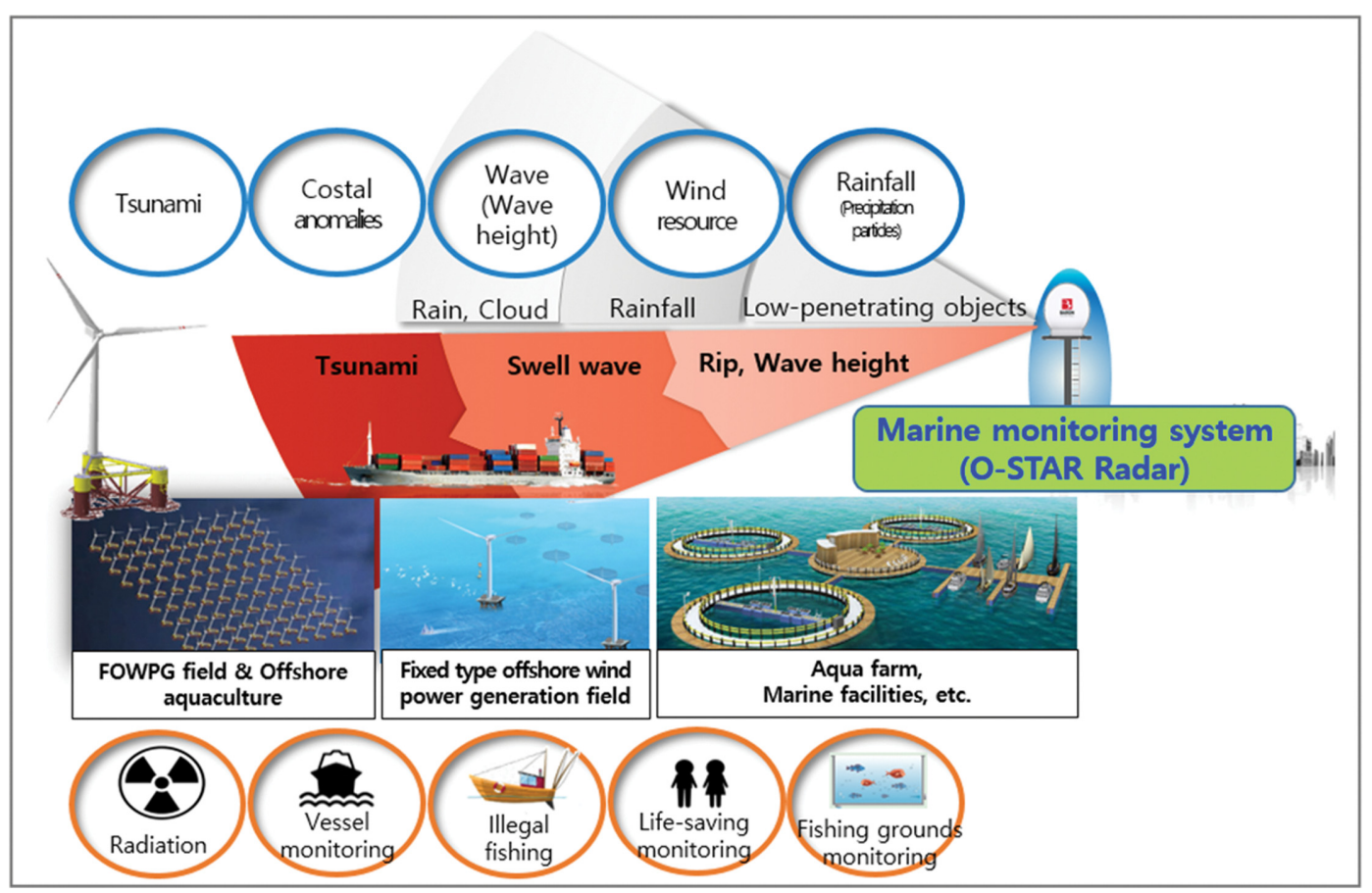

Fig. 5. Example of operation tech. linked to FOWPG field monitoring system.

Fig. 5는 본 연구에 포함된 공존형 모델인 부유식 해상풍력 발전단지 및 가두리 양식장 관리를 위한 해상 관측 및 실시간 모니터링 시스템인 신기술 O-STAR(Ocean Space Technology Analysis Recording) Radar 예시를 나타낸 것으로 관측대상 해역에 $\mathrm{X}, \mathrm{Ka}$ 밴드 레이더를 통한 기상데이터를 참조, $\mathrm{AI}$ 보 정을 통해 해상풍력발전단지 등 해상시설물 보호 및 안전 대 응을 위한 실시간 원격 감시가 가능하다.

\section{3. 공존모델 부가적 효과}

\section{1 해상풍력발전단지 발전 수익}

대규모 부유식 해상풍력발전단지 조성은 재생에너지 보급 목표달성과 전력생산이다. Table 6과 같이 해상풍력발전단지 $0.5 \mathrm{GW}$ 운영을 통해 2020년 발전단가 적용 시 전력판매 수 익 4,107 억 원, 정부의 동남권 부유식 해상풍력발전 $4.6 \mathrm{GW}$ 조성 목표와 2030년 발전단가 132 165원 $/ \mathrm{kWh}$ 를 적용했을 경우 9,600억 원의 수익을 기대할 수 있다. 풍력발전단지에
서 발생하는 전력은 가두리 자동화 운영의 전력공급원 역할 도 할 수 있다. 또한, 연간 64 만 $\mathrm{CO}_{2}$ 절감효과가 있으며 탄 소 배출거래 시 129 억 원 배출권 수익을 예상할 수 있다.

\section{2 관광산업 파급효과}

동해 부유식 해상풍력발전단지 조성과 연계한 참다랑어 양 식장 관광 중심의 수입예측은 경북 영덕군 풍력발전단지 및 영덕 대게 축제기준으로 추정하였다. Table 7과 같이 2019년 풍력발전단지 방문객은 762,997명/년이며 유람선 탑승 규모, 이용률을 고려하여 해상풍력발전단지와 연계한 관광 수입은 연간 22.5 억 원, 참다랑어 음식 관광 수입은 491 억 원이 발 생할 것으로 예측되었다.

\section{3 대표 어종 대체효과}

동해 대표 수산물인 붉은 대게는 어민의 주요 소득원이지 만 기후변화 등의 영향으로 생산량은 지속해서 감소하고 있 으며, 지수함수 예측모델을 통해 해상풍력발전단지 내 참다

Table 6. Predicting profit by operating FOWPG field

\begin{tabular}{|c|c|c|}
\hline Item & Profit(unit: $\left.10^{6} \times \mathrm{KRW}\right)$ & Remark \\
\hline \multirow{2}{*}{$\begin{array}{l}\text { Power } \\
\text { generation } \\
\text { sales }\end{array}$} & $\begin{array}{l}500,000 \mathrm{~kW} \times 8,760 \mathrm{~h}(\text { Time }) \times 0.95(\text { Utilization rate }) \\
\times 0.35 \text { (Utilization factor } \times 0.000282 \mathrm{KRW} / \mathrm{kWh}=410,691 \mathrm{KRW}\end{array}$ & Electricity cost: $2020 \mathrm{Y}$ \\
\hline & 964,191 KRW & $\begin{array}{l}\text { - Electricity cost: } \\
0.000165 \mathrm{KRW} / \mathrm{kWh}(2030 \mathrm{Y}) \\
\text { - } 2 \mathrm{GW}\end{array}$ \\
\hline $\begin{array}{l}\text { GHG } \\
\text { Emission } \\
\text { Trading }\end{array}$ & $\begin{array}{l}1,456,350 \mathrm{MWh} \times 0.4415 \mathrm{tCO}_{2} / \mathrm{MWh} \times 0.02 \mathrm{KRW} \\
(\text { Emission price })=12,860 \mathrm{KRW}\end{array}$ & Emission price: $2020 \mathrm{Y}$ \\
\hline
\end{tabular}


Table 7. Annual tourist industry economic effects

\begin{tabular}{|c|c|c|c|}
\hline & & Economic result(unit: $10^{6} \times \mathrm{KRW}$ ) & Remark \\
\hline \multirow{2}{*}{$\begin{array}{l}\text { Excursion } \\
\text { ship tour }\end{array}$} & $\begin{array}{l}\text { Facility } \\
\text { capacity }\end{array}$ & $\begin{array}{l}150 \text { ppl. (boarding scale) } \times 3 \text { times } / \text { day } \times 200 \text { day } \\
(\text { Number of days to visit, sailable days }) \\
=90,000 \text { people }\end{array}$ & $\begin{array}{l}\text { Sailing time: } \\
3 \sim 3.5 \mathrm{hr}\end{array}$ \\
\hline & $\begin{array}{l}\text { Estimate } \\
\text { effect }\end{array}$ & $\begin{array}{l}45,000 \mathrm{ppl} \text {. (Expected tourist) } \times 0.05 \mathrm{KRW} \\
(\text { Admission fee, tasting tuna }) \\
=2,250 \mathrm{KRW}\end{array}$ & $\begin{array}{l}\text { Ship occupancy } \\
\text { rate: } 50 \%\end{array}$ \\
\hline \multirow{2}{*}{$\begin{array}{l}\text { Food } \\
\text { tourism }\end{array}$} & \multirow{2}{*}{$\begin{array}{c}\text { Estimate } \\
\text { effect }\end{array}$} & $\begin{array}{l}78,876 \mathrm{ppl} \text {. (Festival tourist) } \times 0.111636 \mathrm{KRW} / \mathrm{ppl} \text {. } \\
=8,805.4 \mathrm{KRW}\end{array}$ & $\begin{array}{l}\text { Yeongdeok snowcrab } \\
\text { festival visitor: } \\
78,876 \text { ppl. }\end{array}$ \\
\hline & & $\begin{array}{l}3,669,249 \mathrm{ppl} . \times 0.22(\text { Epicureanism travel rate }) \\
\times 0.05 \mathrm{KRW} \\
=40,361.7 \mathrm{KRW}\end{array}$ & $\begin{array}{l}\text { Ganggu Port visitor: } \\
3,669,249 \text { ppl. }\end{array}$ \\
\hline
\end{tabular}

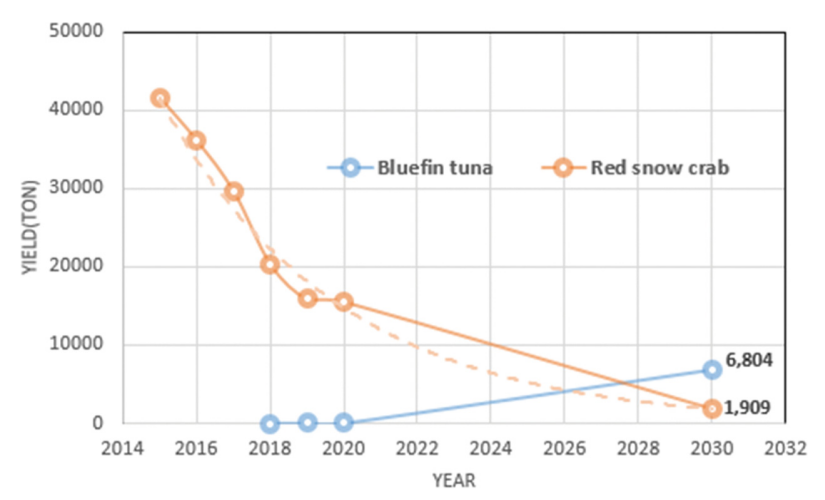

Fig. 6. Comparative prediction of bluefin tuna and red snow crab production.

랑어 양식의 소득 대체 및 창출 가능성을 예측하였다. 2020 년 기준 양식 참다랑어는 4.4 만 원 $/ \mathrm{kg}$ (생산량 26 톤, 생산금액 1,133 백만 원)이 생산, 판매되었으며, Fig. 6 은 $0.5 \mathrm{GW}$ 해상 풍력발전단지 조성 기준으로 2030년까지 붉은 대게 및 참다 랑어 생산량을 나타내었다. 2028년 이후 참다랑어는 6,804톤, 대게는 1,900 톤으로 생산량 대체효과로 주요 소득원이 될 것 으로 추정된다.

\section{4. 결 론}

본 연구에서는 동해 부유식 해상풍력발전단지 조성과 공존 할 수 있는 모델로서 참다랑어 양식장 조성 방안을 제시하고 경제적 효과를 검토하여 해상 공유 가능성을 확인하였다. 기 후변화에 따른 어종과 생산량 변화로 필연적 선택을 통한 소 득원 창출이 요구되고 정책적 에너지 개발 목표달성, 양식산 업의 스마트화 구축 시점에서 부유식 해상풍력발전의 특성상 수심 $100 \mathrm{~m}$ 내외에서 설치할 수 있으며 단지 내 조성 방안 으로 고정식 해상풍력발전단지 수산 공존모델과는 차별화할 수 있었다.

해상풍력발전 단지 내에 참다랑어 양식을 위한 종자 또는 치어 확보는 기존의 수입방식 또는 남해 또는 제주에서 이송
하는 방식 대신 기후온난화 영향으로 동해의 정치망 포획량 이 증가하고 있는 참다랑어를 약 18 개월 사육, $30 \mathrm{~kg}$ 정도에 서 판매하는 방안으로 2030 년 $0.5 \mathrm{GW}$ 단지 내 81 개 이상의 가두리를 설치한다면 378 억 원의 수익을 예측할 수 있었다. 또한, 해상풍력발전단지 운영관리 기술을 공유하여 개발하고 기반 시설물 및 모니터링 시스템을 연계하여 활용한다면 예 산의 중복투자를 피하고 외해양식의 스마트 관리가 가능할 것 이다. 수산공존모델의 부가적 수익은 해상풍력발전단지 전력 판매 4,107억 원이며 탄소 배출권으로 환산할 경우 129 억 원 으로 추정되었다. 관광자원으로서 해상 풍력단지와 참다랑어 양식장 현장체험을 통한 22.5 억 원과 육상 축제 및 음식 관 광 수입 491억 원으로 직접적 발생 수익은 연간 총 513.5억 으로 나타났다. 동해 대표 브랜드인 붉은 대게 대비 참다랑 어 양식 생산량 대체효과는 2028년 이후 가능하며, 주요 소 득원으로 자리 잡을 수 있을 것으로 분석되었다.

에너지 정책, 수산양식의 글로벌화에 대응하고 동해의 특 성을 반영한 부유식 해상풍력발전단지 조성과 참다랑어 양식 의 공존 실현을 위해 참다랑어 동해 어획 쿼터 해결방안, 사 회적 수용성 제고를 위한 방안으로써 정책적 관심이 요구된다.

\section{References}

Choi, E.J., Kim, H.W. and Kim, J.H. (2015). An Economical Feasibility Analysis of Sea Farm Project Using Co-Location in Offshore Wind Farms. Journal of Product Research, 33(6), 73-80.

Choi, G.W., Jung, R.T., Lee, B.H. and Shin, K.B. (2018). Research for Validity of Building Offshore Floating Wind Power Field at East Sea and Compatibility of Floating Wind Turbine Generator. Journal of Korean Society for Marine Environment and Energy, 21(2), 64-75.

Choi, G.W., Kim, M.J, Jang, K.H., Jun, J.C. and Park, J.J. (2019). A Study of the Development of a Concrete Floating Breakwater for an Open Sea Fish Farm. Journal of Ocean Engineering and Technology, Vol. 33, No. 6, 648-656.

Choi, G.W. (2019). Development of the integrated analysis model of the floating type offshore wind-turbine and its economic eval- 
uation: Focus on floating wind farm at East Sea in Korea, Doctoral dissertation, University of Ulsan.

Kang, K.S., Jeon, I.S. and Kwak, J.Y. (2016). Possibilities and Orientation toward Co-existence of Offshore Wind Farms. Journal of Wind Energy, 7(2), 5-13.

Kim, D.N., Lee, M.K., Lee, S.I. and An, D.H. (2019). Update of Korean fisheries information for Pacific bluefin tuna, Thunnus orientalis. National Institute of Fisheries Science.

Lee, D.G., Bae, B.S., Lee, J.H., Kim, S.T. and Kim, H.S. (2021). Development of the Smart Aquaculture Technology and Industrialization Plan. The Korean Society Fisheries And Sciences Education, 33(2), 412-420.
National Institute of Fisheries Science (2012). Economic feasibility study for deep-sea aquaculture technology development and aquaculture in connection with offshore wind power.

Wei, H. (2015). Jacket-Cage: Dual-Use the Jacket Foundation of Offshore Wind Turbine for Aquaculture Farming. Wind Engineering, 39(3), 311-320.

Received 11 June, 2021

Revised 22 June, 2021

Accepted 22 June, 2021 